\title{
Structural, mechanical and in vitro corrosion characterization of as-cast magnesium based alloys for temporary biodegradable medical implants
}

Dalibor Vojtěch, Jiří Kubásek, Milena Voděrová

Department of Metals and Corrosion Engineering, Institute of Chemical Technology, Prague, Technická 5, 16628 Prague 6, Czech Republic. Dalibor.Vojtech@vscht.cz

Magnesium based alloys are light-weight materials having a good strength to weight ratio making them of interest for many structural applications in automotive and aerospace industry. Besides, magnesium is also considered as promising metal for construction of temporary biodegradable medical implants like stents or fixation devices for fractured bones. A biodegradable implant progressively corrodes in the human body fluids and is replaced by the healing tissue. No second surgery is needed to remove the implant after the bone has healed. The advantage of magnesium is that it is relatively non-toxic metal and that its mechanical characteristics (strength, Young's modulus) are close to those of natural bone. But pure magnesium is not very suitable, because it has a low strength and too high corrosion rate in comparison with the rate of bone tissue healing. Therefore, a great effort has been devoted to find suitable magnesium based alloys which possess sufficient strength levels and low corrosion rates in the human body. This paper presents structural, mechanical and corrosion properties of magnesium based alloys containing zinc, rare earth metals and zirconium as the main alloying elements.

Keywords: magnesium, biodegradable implant, corrosion, mechanical properties

\section{Acknowledgements}

Research on biodegradable magnesium based alloys is financially supported by the Czech Science Foundation (project no. P108/12/G043) and Technology Agency of the Czech Republic (project no. TE01020390).

\section{References}

[1] DAVIS, J.R. (2003). Handbook of materials for medical devices, pp. 341. ASM International, Materials Park.

[2] STAIGER, M.P., PIETAK, A.M., HUADMAI, J., et al. (2006). Magnesium and its alloys as orthopedic biomaterials: A review. Biomaterials, 27, 9, pp. 1728-1734.

[3] XIN, Y., HU, T.,CHU, P.K. (2011). In vitro studies of biomedical magnesium alloys in a simulated physiological environment: A review. Acta Biomaterialia, 7, 4, pp. 1452-1459.

[4] TALBOT, D.E.J.,TALBOT, J.D.R. (2007). Corrosion Science and Technology, pp. 552. CRC PRESS.

[5] WITTE, F., HORT, N., VOGT, C., et al. (2008). Degradable biomaterials based on magnesium corrosion. Current Opinion in Solid State and Materials Science, 12, 5-6, pp. 63-72.

[6] ZHANG, S., ZHANG, X., ZHAO, C., et al. (2010). Research on an Mg-Zn alloy as a degradable biomaterial. Acta Biomaterialia, 6, 2, pp. 626-640.

[7] ZENG, R., DIETZEL, W., WITTE, F., et al. (2008). Progress and Challenge for Magnesium Alloys as Biomaterials. Advanced Engineering Materials, 10, 8, pp. B3-B14.

[8] SONG, G. (2007). Control of biodegradation of biocompatable magnesium alloys. Corrosion Science, 49, 4, pp. 1696-1701.

[9] WITTE, F. (2010). The history of biodegradable magnesium implants: A review. Acta Biomaterialia, 6, 5, pp. 1680-1692.

[10] VOJTĚCH, D., ČÍŽOVÁ, H.,VOLENEC, K. (2006). Investigation of magnesium-based alloys for biomedical applications. Kovové materiály, 44, 4, pp. 211-223.

[11] LI, Z., GU, X., LOU, S., et al. (2008). The development of binary Mg-Ca alloys for use as biodegradable materials within bone. Biomaterials, 29, 10, pp. 1329-1344.

[12] XU, L., PAN, F., YU, G., et al. (2009). In vitro and in vivo evaluation of the surface bioactivity of a calcium phosphate coated magnesium alloy. Biomaterials, 30, 8, pp. 1512-1523.

[13] HIROMOTO, S., SHISHIDO, T., YAMAMOTO, A., et al. (2008). Precipitation control of calcium phosphate on pure magnesium by anodization. Corrosion Science, 50, 10, pp. 2906-2913.

[14] CELAREK, A., KRAUS, T., TSCHEGG, E.K., et al. (2012). PHB, crystalline and amorphous magnesium alloys: Promising candidates for bioresorbable osteosynthesis implants? Materials Science and Engineering: $C$, 32,6 , pp. 1503-1510. 
[15] KIRKLAND, N.T., BIRBILIS, N.,STAIGER, M.P. (2012). Assessing the corrosion of biodegradable magnesium implants: A critical review of current methodologies and their limitations. Acta Biomaterialia, 8, 3, pp. 925-936.

[16] ERDMANN, N., ANGRISANI, N., REIFENRATH, J., et al. (2011). Biomechanical testing and degradation analysis of $\mathrm{MgCa} 0.8$ alloy screws: A comparative in vivo study in rabbits. Acta Biomaterialia, 7, 3, pp. 14211428.

[17] CASTELLANI, C., LINDTNER, R.A., HAUSBRANDT, P., et al. (2011). Bone-implant interface strength and osseointegration: Biodegradable magnesium alloy versus standard titanium control. Acta Biomaterialia, 7, 1, pp. $432-440$.

[18] KAINER, K.U. (2006). Masgnesium - Alloys and Technologies, pp. 293. Wiley-VCH, Weinheim.

[19] GALE, W.F.,TOTEMEIER, T.C. Smithells Metals Reference Book (8th Edition), Elsevier.

[20] TAKENAKA, T., ONO, T., NARAZAKI, Y., et al. (2007). Improvement of corrosion resistance of magnesium metal by rare earth elements. Electrochimica Acta, 53, 1, pp. 117-121.

[21] YAO, H.B., LI, Y., WEE, A.T.S., et al. (2001). Correlation between the corrosion behavior and corrosion films formed on the surfaces of $\mathrm{Mg} 82-\mathrm{xNi} 18 \mathrm{Ndx}(\mathrm{x}=0,5,15)$ amorphous alloys. Applied Surface Science, 173, 1-2, pp. 54-61.

[22] ATRENS, A., LIU, M.,ZAINAL ABIDIN, N.I. (2011). Corrosion mechanism applicable to biodegradable magnesium implants. Materials Science and Engineering: B, 176, 20, pp. 1609-1636.

Paper number: M201260

Manuscript of the paper received in 2012-09-13. The reviewers of this paper: Petr Jurci, Ivan Lukac. 